\title{
Modulation by 1,25-Dihydroxycholecalciferol of the Acute Change in Cytosolic Free Calcium Induced by Thyrotropin-releasing Hormone in $\mathrm{GH}_{4} \mathrm{C}_{1}$ Pituitary Cells
}

Jane C. Chisholm, Scott Kim, and Armen H. Tashjian, Jr. Laboratory of Toxicology, Harvard School of Public Health and Department of Biological Chemistry and Molecular Pharmacology, Harvard Medical School, Boston, Massachusetts 02115

\section{Abstract}

Receptor-mediated regulation of prolactin synthesis by 1,25 dihydroxycholecalciferol $\left(1,25(\mathrm{OH})_{2} \mathrm{D}_{3}\right)$ in the pituitary cell strain $\mathbf{G H}_{4} \mathbf{C}_{1}$ is dependent on the concentration of extracellular calcium. We have now investigated the actions of $1,25(\mathrm{OH})_{2} \mathrm{D}_{3}$ on cytosolic free calcium concentrations $\left(\left[\mathrm{Ca}^{2+} \mathrm{li}_{\mathrm{i}}\right)\right.$ in these cells using the fluorescent indicator quin2. Basal resting $\left[\mathrm{Ca}^{2+}\right]_{1}$ was unchanged in cells treated with $1 \mathrm{nM}$ $1,25(\mathrm{OH})_{2} \mathrm{D}_{3}$ either acutely (from 0 to $15 \mathrm{~min}$ ) or for periods of up to $48 \mathrm{~h}$. However, the initial peak of the biphasic change in $\left[\mathrm{Ca}^{2+}\right]_{\mathrm{i}}$ induced by thyrotropin-releasing hormone (TRH) was enhanced more than twofold in cells pretreated for 24 or $48 \mathrm{~h}$ with $1,25(\mathrm{OH})_{2} \mathrm{D}_{3}$. This $1,25(\mathrm{OH})_{2} \mathrm{D}_{3}$-enhanced calcium response was restricted to the initial phase of TRH action; the secondary plateau phase was unaffected. Neither the affinity nor number of TRH receptors nor the early time course of [ $\left.{ }^{3} \mathrm{H}\right] \mathrm{MeTRH}$ binding to $\mathrm{GH}_{4} \mathrm{C}_{\mathbf{1}}$ cells were affected by pretreatment with $1,25(\mathrm{OH})_{2} \mathrm{D}_{3}$. Because TRH binding was not altered, four sites along the intracellular signal transduction pathway of TRH action were examined. Neither protein kinase C activation nor inositol polyphosphate accumulation were enhanced in response to $\mathrm{TRH}$, in $1,25(\mathrm{OH})_{2} \mathrm{D}_{3}$ pretreated cells, indicating that phosphatidylinositol hydrolysis was unchanged by pretreatment. A low concentration of ionomycin was used to probe the size of the nonmitochondrial intracellular calcium pool that is sensitive to TRH. Ionomycin was not able to mobilize more calcium from $1,25(\mathrm{OH})_{2} \mathrm{D}_{3}$ pretreated cells, indicating that TRH-responsive intracellular calcium stores were probably not enhanced by pretreatment. Chelation of extracellular calcium, however, did eliminate enhancement of the TRH response in $1,25(\mathrm{OH})_{2} \mathrm{D}_{3}$-pretreated cells. We conclude that $1,25(\mathrm{OH})_{2} \mathrm{D}_{3}$ modulates acute dynamic changes in $\left[\mathrm{Ca}^{2+}\right]_{1}$ induced by TRH without affecting basal $\left[\mathrm{Ca}^{2+}\right]_{j}$. The mechanism of the enhanced response of $1,25(\mathrm{OH})_{2} \mathrm{D}_{3}$-pretreated cells to TRH appears to depend upon a postreceptor event independent of phosphatidylinositol hydrolysis that involves increased calcium conductance at the level of the plasma membrane. A less likely explanation involves enhancement of intracellular calcium stores in an ionomycin-resistant, EGTA-sensitive, TRHmobilizable reservoir.

Address reprint requests to Dr. Chisholm, Laboratory of Toxicology, Harvard School of Public Health, 665 Huntington Avenue, Boston, MA 02115.

Received for publication 6 February 1987 and in revised form 2 October 1987.

J. Clin. Invest.

(c) The American Society for Clinical Investigation, Inc. 0021-9738/88/03/0661/08 $\$ 2.00$

Volume 81, March 1988, 661-668

\section{Introduction}

Mobilization of sequestered calcium from an intracellular reservoir to form transient elevations in $\left[\mathrm{Ca}^{2+}\right]_{i}{ }^{1}$ is a key component in the intracellular signal transduction pathway for many hormones, and a well-characterized response to agents that act via the metabolism of phosphatidylinositol (1-3). Increases in $\left[\mathrm{Ca}^{2+}\right]_{\mathrm{i}}$ are a specific requirement in thyrotropin-releasing hormone (TRH)-induced secretion $(4,5)$, and these increases have been investigated in detail using the growth hormone (GH) clonal rat pituitary cell strains (6-8). These cells also display receptor-mediated responses to the calcium mobilizing steroid hormone $1,25(\mathrm{OH})_{2} \mathrm{D}_{3}(9,10)$. Thus, $\mathrm{GH}_{4} \mathrm{C}_{1}$ cells represent a nonclassical target cell model for this hormone. Treatment of $\mathrm{GH}_{4} \mathrm{C}_{1}$ cells with low concentrations of $1,25(\mathrm{OH})_{2} \mathrm{D}_{3}$ in hormone-free, chemically defined medium induces increases in prolactin (PRL) synthesis (9). The effects of the steroid are specific to PRL, with no increase in growth hormone production. Furthermore, these responses are dependent upon calcium, as determined by changing the extracellular concentration of this ion $(9,10) .1,25(\mathrm{OH})_{2} \mathrm{D}_{3}$ has long been known to increase calcium transport across gut epithelium, in the distal renal tubule and in bone, although the mechanism underlying this transport remains unknown $(11,12)$. Because $\mathrm{GH}_{4} \mathrm{C}_{1}$ cells demonstrate both a responsiveness to $1,25(\mathrm{OH})_{2} \mathrm{D}_{3}$ that depends upon calcium, and an important dependence upon calcium in signal transduction for TRH-mediated events, we have examined the actions of $1,25(\mathrm{OH})_{2} \mathrm{D}_{3}$ on TRH-induced regulation of $\left[\mathrm{Ca}^{2+}\right]_{i}$ in these cells.

The cytosolic free calcium response to the binding of TRH to its membrane receptor is biphasic $(4,5)$. The initial rapid peak (phase I) occurs within the first minute after addition of TRH. When cells are grown in serum-free medium containing $400 \mu \mathrm{M}$ calcium, TRH increases $\left[\mathrm{Ca}^{2+}\right]_{\mathrm{i}}$ levels $\sim 2.6$-fold above basal levels. The majority of the calcium comprising this peak $(\sim 85 \%)$ is mobilized from nonmitochondrial intracellular stores that are resistant to chelation of extracellular calcium and are selectively depleted by prior administration of $100 \mathrm{nM}$ ionomycin (5). This calcium ionophore is preferentially soluble in intracellular membranes as indicated by its ability to cause a cytosolic calcium peak in the face of chelation of extracellular calcium (5), and independently of changes in phosphatidylinositol metabolism (13). TRH and ionomycin, at this low concentration, access the same intracellular calcium store in that prior administration of either agent essentially eliminates the peak response to the other (5). The acute TRH-in-

1. Abbreviations used in this paper: $\left[\mathrm{Ca}^{2+}\right]_{\mathrm{i}}$, cytosolic free calcium concentration; DAG, diacylglycerol; $f_{\min }, f_{\max }$, minimum, maximum fluorescence; HBSS, Hepes buffered saline solution; $\mathrm{IP}_{3}$, inositol trisphosphates; MeTRH, methyl-TRH; $1,25(\mathrm{OH})_{2} \mathrm{D}_{3}, 1,25$-dihydroxycholecalciferol; quin2-AM, quin2 acetoxymethyl ester; TRH, thyrotropin-releasing hormone. 
duced spike in $\left[\mathrm{Ca}^{2+}\right]_{i}$ occurs in association with the phosphodiesteratic hydrolysis of phosphatidylinositol to the protein kinase C-stimulating agent, diacylglycerol (DAG) and inositol trisphosphates $\left(\mathrm{IP}_{3}\right)^{2}(13-15)$. $\mathrm{IP}_{3}$ is currently believed to be the mediator responsible for releasing $\mathrm{Ca}^{2+}$ from intracellular stores (16). Subsequent to the nadir of this first phase in elevated $\left[\mathrm{Ca}^{2+}\right]_{i}$, a second plateau (phase II) of elevated $\left[\mathrm{Ca}^{2+}\right]_{i}$ occurs within $3 \mathrm{~min}$, and is sustained over a long period ( $>30$ $\min )$ in the continued presence of $\operatorname{TRH}(4,5)$. This second phase is unaffected by pretreatment of the cells with ionomycin but, unlike phase I, it is eliminated by EGTA, verapamil, or nifedipine, indicating its dependence on influx of extracellular calcium through voltage-sensitive calcium channels $(4,5)$.

The experiments presented in this report describe an enhancement of the $\left[\mathrm{Ca}^{2+}\right]_{\mathrm{i}}$ response to $\mathrm{TRH}$ receptor activation in cells that were pretreated with $1,25(\mathrm{OH})_{2} \mathrm{D}_{3}$, and examine the site at which this steroid hormone acts to modulate the response to TRH.

\section{Methods}

Cell culture. $\mathrm{GH}_{4} \mathrm{C}_{1}$ cells were grown in monolayer culture in Ham's F10 nutrient mixture supplemented with $15 \%$ horse serum and $2.5 \%$ fetal bovine serum as described previously $(17,18)$. Cells were harvested, using Hepes buffered saline solution (HBSS) II buffer $(118 \mathrm{mM}$ $\mathrm{NaCl}, 4.6 \mathrm{mM} \mathrm{KCl}, 10 \mathrm{mM}$ D-glucose, $20 \mathrm{mM}$ Hepes, $400 \mu \mathrm{M} \mathrm{CaCl}_{2}$, $\mathrm{pH}$ 7.2) lacking calcium and containing $0.02 \%$ EDTA, $72 \mathrm{~h}$ before experimentation and transferred to $100-\mathrm{mm}$ Petri dishes in a hormone-free chemically defined medium containing $\mathrm{CaCl}_{2}(0.4 \mathrm{mM})$ as described previously (9). Cells were treated with $1 \mathrm{nM} 1,25(\mathrm{OH})_{2} \mathrm{D}_{3}$ or vehicle $\left(1 \times 10^{-4} \%\right.$ ethanol) for the times indicated in the figures and tables. Cells were harvested by gentle trituration, pelleted by low speed centrifugation $(250 \mathrm{~g}, 2 \mathrm{~min})$ and resuspended in fresh HBSS II. After pelleting again, cells were resuspended finally in fresh HBSS II.

Measurement of $\left[\mathrm{Ca}^{2+}\right]_{i}$. Cells $\left(5-15 \times 10^{6}\right)$ were incubated for 30 min at $37^{\circ} \mathrm{C}$ in HBSS II in the presence of $50 \mu \mathrm{M}$ quin2-AM, a lipid soluble probe which, when hydrolyzed by intracellular esterases, fluoresces in response to bound calcium $(19,20)$. Cells were then washed free of nonhydrolyzed quin2-AM by pelleting three times from suspension in fresh HBSS II and finally resuspended for fluorescence monitoring in a fluorescence spectrophotometer (model 650-10S; PerkinElmer Corp., Norwalk, CT) with $\lambda_{e x}=339 \mathrm{~nm}$ and $\lambda_{\mathrm{em}}=492 \mathrm{~nm}$ and slit widths each of $5 \mathrm{~nm}$. Cells were maintained at $37^{\circ} \mathrm{C}$ throughout the experiments in a continuously stirred suspension $(2.5 \mathrm{ml}) .\left[\mathrm{Ca}^{2+}\right]_{\mathrm{i}}$ was quantified using the equation: $\left[\mathrm{Ca}^{2+}\right]_{\mathrm{i}}=K_{\mathrm{d}}\left(F-F_{\min } / F_{\max }-F\right)$, where $K_{d}=115 \mathrm{nM}, F=$ fluorescent signal in arbitrary units, and $F_{\max }$ and $F_{\min }$ were determined as described previously (4). Calibration was performed by permeabilizing the cells with $25 \mu \mathrm{M}$ digitonin in the presence of $2 \mathrm{mM} \mathrm{CaCl}_{2}$ to achieve a maximal fluorescent signal $\left(F_{\max }\right)$ and chelating the calcium with $10 \mathrm{mM}$ excess EGTA (pH adjusted to $>8.3$ with Tris base) to determine the background fluorescence $\left(F_{\min }\right)$. None of the compounds used produced significant autofluorescence or changed $F_{\max }$ at $339 \mathrm{ex}, 492 \mathrm{em}$ when tested alone or in combination. Test drugs were added from 200 -fold concentrated stock solutions except the Tris and EGTA calibration stock solutions, which were from 100 -fold concentrated stock solutions. Additions were made directly to the cuvette in the spectrofluorometer at the times indicated. Statistical analyses for these and the following experiments were performed using Student's $t$ test for significant difference.

Measurement of $\left[{ }^{3} \mathrm{H}\right]$-methyl TRH binding to intact cells. Cells were maintained in chemically defined medium for $72 \mathrm{~h}$, including a

2. The term $\mathrm{IP}_{3}$ is used to include both inositol $(1,4,5)$ trisphosphate and inositol $(1,3,4)$ trisphosphate. See Drummond $(30)$ for comment on the presence of the $1,3,4$ trisphosphate isomer in this fraction. final 48-h exposure to $1 \mathrm{nM} 1,25(\mathrm{OH})_{2} \mathrm{D}_{3}$ or vehicle. Media was aspirated on the day of the experiment, culture wells were rinsed twice with $1.5 \mathrm{ml} \mathrm{HBSS} \mathrm{II,} \mathrm{and} \mathrm{[}{ }^{3} \mathrm{H}$ ]MeTRH was added without or with $1.5 \mu \mathrm{M}$ unlabeled MeTRH in $1 \mathrm{ml}$ of HBSS II. Binding incubations were terminated after $60 \mathrm{~min}$ at $37^{\circ} \mathrm{C}$ by aspirating the media and plunging the plates three times into an ice-cold saline wash. Monolayers were solubilized in $1,200 \mu \mathrm{l}$ of $0.1 \mathrm{M} \mathrm{NaOH}$, and transferred to vials for liquid scintillation counting, using Aquasol. Specific binding was determined as the amount of bound radioactivity displacable by $1 \mu \mathrm{M}$ unlabeled TRH (nonspecific binding).

Measurement of protein kinase $C$ activity. Cells $\left(1-2 \times 10^{7}\right)$ suspended in HBSS II were treated, as described previously $(21,22)$, with or without $1.0 \mu \mathrm{M}$ TRH for $15 \mathrm{~s}$ and the reaction stopped by breaking the cells in $20 \mathrm{mM}$ Tris, $1 \mathrm{mM}$ EDTA, $0.5 \mathrm{mM}$ dithiothreitol (pH 7.5) by passage through a 28 -gauge needle. Soluble cytosol was separated from membrane fractions by centrifugation at $20,000 \mathrm{~g}$ for $10 \mathrm{~min}$. Particulate (membrane) material was resuspended in $400 \mu$ l of the same buffer in the presence of $1 \%$ Triton X-100. Both the cytosol and particulate fractions were applied to separate diethylaminoethyl cellulose columns and protein kinase $C$ activity was eluted with $80 \mathrm{mM}$ $\mathrm{NaCl}$. Phospholipid and calcium-dependent enzymatic activity was measured as the transfer of ${ }^{32} \mathrm{P}$ from ATP $\left(5 \mathrm{nmol}, \sim 6 \times 10^{5} \mathrm{cpm}\right)$ to a histone acceptor protein (H III-S) in the presence of $25 \mathrm{mM} \mathrm{Tris} / \mathrm{HCl}$, $\mathrm{pH} 7.5,1.5 \mu \mathrm{mol}$ magnesium acetate, $100 \mathrm{nmol} \mathrm{CaCl}_{2}, 25 \mu \mathrm{g}$ of phosphatidylserine, $2 \mu \mathrm{g}$ of diolein and $100 \mu \mathrm{g}$ of histone in a total volume of $200 \mu \mathrm{l}(21,22)$. Radioactivity was determined by liquid scintillation counting of a trichloroacetic acid precipitate collected by filtration through $0.45 \mu \mathrm{m}$ membrane filters (HAWP; Millipore Corp., Bedford, MA).

Determination of inositol phosphate formation. Myo- $\left[2-{ }^{3} \mathrm{H}(N)\right]$ inositol $(8 \mu \mathrm{Ci} / 10 \mathrm{ml})$ was added to the cells as described previously $(23)$ at the time of plating in serum-free medium $72 \mathrm{~h}$ before experimentation. Cells were harvested as described above and incubated for $30 \mathrm{~min}$ at $37^{\circ} \mathrm{C}$ before stimulation with $1.5 \mu \mathrm{M}$ TRH. Treatment was stopped by the addition of ice-cold trichloroacetic acid (TCA) (10\% final concentration). The precipitate was removed by centrifugation and the soluble fraction stored at $-20^{\circ} \mathrm{C}$ frozen for up to $1 \mathrm{wk}$ before assay. Etherextracted, water-soluble fractions were separated on a $1 \times 2$-cm Dowex AG-1 XB anion exchange resin using $\mathrm{HCl}(30-500 \mathrm{mM})$ as the eluants (24). Metabolites were quantified by liquid scintillation counting of the separated fractions. Validation of this chromatographic method has been obtained by comparison with the elution pattern of authentic $\left.{ }^{32} \mathrm{P}\right] \mathrm{IP}_{3}$ (23).

Materials. Culture media, sera, and reagents (amino acids, vitamins, and salts) used in the chemically defined media (MEM-SS) were obtained from Gibco (Grand Island, NY). Quin2-acetoxymethyl ester (quin2-AM) was purchased from Lancaster Synthesis (Lancashire, England). TRH was a gift from Dr. Eugene Woroch, Abbott Laboratories (North Chicago, IL). Ionomycin was a gift from Dr. Chao-Min Liu, and 1,25-dihydroxyvitamin $D_{3}$ was from $\mathrm{Dr}$. M. Uskokovic, both from Hoffman-LaRoche (Nutley, NJ). Digitonin was purchased from Fisher Scientific Co. (Fair Lawn, NJ) and EGTA from Eastman Kodak Co. (Rochester, NY). Myo-[2- $\left.{ }^{3} \mathrm{H}(N)\right]$ inositol (SA $14 \mathrm{Ci} \mathrm{mmol}^{-1}$ ) was obtained from American Radiolabeled Chemicals (St. Louis, MO). $\left[{ }^{3} \mathrm{H}\right]-$ MeTRH (sp act $76 \mathrm{Ci} \mathrm{mmol}^{-1}$ ), [ $\left.\gamma^{32} \mathrm{P}\right] \mathrm{ATP}$ (sp act $1,000 \mathrm{Ci} \mathrm{mmol}^{-1}$ ) and Aquasol were obtained from New England Nuclear (Boston, MA). Dowex AG-1 $\times 8$ (200-400 mesh) anion exchange resin and DEAE were obtained from Bio-Rad, Richmond, CA. All other chemicals were reagent grade and purchased from Sigma Chemical Co. (St. Louis, MO).

\section{Results}

Basal and TRH-stimulated $\left[\mathrm{Ca}^{2+}\right]_{i}$ in cells without and with $1,25(\mathrm{OH})_{2} \mathrm{D}_{3}$ pretreatment. Basal $\left[\mathrm{Ca}^{2+}\right]_{\mathrm{i}}$ was monitored before addition of TRH. Typical traces of fluorescence from quin2-loaded cells are presented in Fig. 1. The difference in 


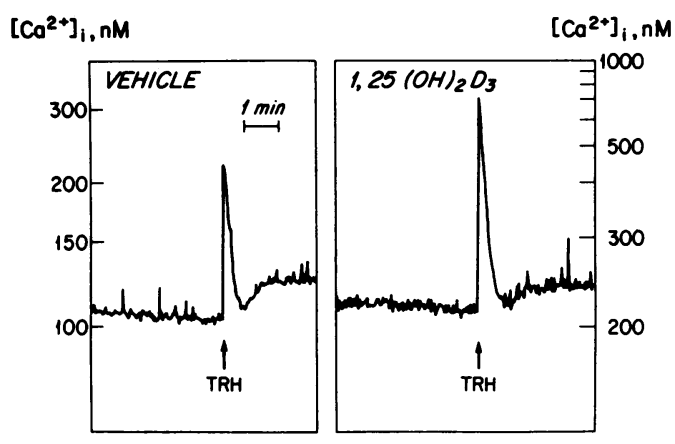

Figure 1. Action of $1,25(\mathrm{OH})_{2} \mathrm{D}_{3}$ on the $\left[\mathrm{Ca}^{2+}\right]_{i}$ response to TRH in $\mathrm{GH}_{4} \mathrm{C}_{1}$ cells. Cells were treated with vehicle or $1,25(\mathrm{OH})_{2} \mathrm{D}_{3}(1 \mathrm{nM})$ for $24 \mathrm{~h}$ before the experiment. Traces show the $\left[\mathrm{Ca}^{2+}\right]_{i}$ as a function of time after resuspension of the cells in the monitoring cuvette. Ordinates present $\left[\mathrm{Ca}^{2+}\right]_{i}$ on the scale transformed from absolute fluorescence units by the equation given in Methods. TRH ( $350 \mathrm{nM})$ was added directly to the cell suspension at the time indicated. For vehicle-treated cells $\left[\mathrm{Ca}^{2+}\right]_{\mathrm{i}}$ values in $\mathrm{nM}$ were: basal, 104; $\mathrm{TRH}_{\text {peak }}, 227$, $\mathrm{TRH}_{\text {plateau }}, 123$. For cells pretreated with $1,25(\mathrm{OH})_{2} \mathrm{D}_{3}$ basal, 212; $\mathrm{TRH}_{\text {peak }}, 719 ; \mathrm{TRH}_{\text {plateau }}, 240$.

basal $\left[\mathrm{Ca}^{2+}\right]_{\mathrm{i}}$ seen in these two traces was not significant $(P$ $>0.05$ ) when multiple experiments were analyzed. TRH produced a qualitatively similar biphasic response pattern in $\left[\mathrm{Ca}^{2+}\right]_{i}$ in control and $1,25(\mathrm{OH})_{2} \mathrm{D}_{3}$-pretreated cells. After addition of a maximal concentration of TRH ( $350 \mathrm{nM})$, an initial peak in $\left[\mathrm{Ca}^{2+}\right]_{\mathrm{i}}$ was achieved within seconds, which decayed rapidly and was followed by a sustained plateau phase of elevated $\left[\mathrm{Ca}^{2+}\right]_{i}$ within 2-3 min. However, the magnitude of the initial peak in $\left[\mathrm{Ca}^{2+}\right]_{\mathrm{i}}$ was considerably larger in cells pretreated for $24 \mathrm{~h}$ with $1 \mathrm{nM} 1,25(\mathrm{OH})_{2} \mathrm{D}_{3}$ than in control vehicle-treated cells.

Data from several experiments of similar design are summarized in Fig. 2 as actual $\left[\mathrm{Ca}^{2+}\right]_{i}$ values, and in Table $I$ as ratios of peak response levels to pre-TRH basal levels of $\left[\mathrm{Ca}^{2+}\right]_{i}$. Mean basal $\left[\mathrm{Ca}^{2+}\right]_{i}$ was not significantly changed by either 24 or $48 \mathrm{~h}$ of pretreatment with $1,25(\mathrm{OH})_{2} \mathrm{D}_{3}$ as compared with control cells. Basal $\left[\mathrm{Ca}^{2+}\right]_{i}$ in $48 \mathrm{~h}$ pretreated and control cells were $222 \pm 15 \mathrm{nM}$ (mean $\pm \mathrm{SE}, n=16$ ) and $186 \pm 18$
Table I. Summary of Ratios of TRH-induced Responses in $\left[\mathrm{Ca}^{2+}\right]_{i}$ to Basal $\left[\mathrm{Ca}^{2+}\right]_{i}$ in Control and $1,25(\mathrm{OH})_{2} \mathrm{D}_{3}$-pretreated Cells

\begin{tabular}{|c|c|c|c|}
\hline \multirow[b]{2}{*}{ Treatment } & \multirow{2}{*}{$\begin{array}{l}\text { Duration of } \\
\text { pretreatment }\end{array}$} & \multicolumn{2}{|c|}{$\left[\mathrm{Ca}^{2+}\right]_{\mathrm{i}}$ Ratio } \\
\hline & & $\mathrm{TRH}_{\text {pent/ranal }}$ & $\mathrm{TRH}_{\text {plemenamom }}$ \\
\hline & $h$ & & \\
\hline Vehicle & 24 & $2.8 \pm 0.21$ & $1.25 \pm 0.07$ \\
\hline $1,25(\mathrm{OH})_{2} \mathrm{D}_{3}$ & 24 & $3.9 \pm 0.45^{*}$ & $1.23 \pm 0.05$ \\
\hline Vehicle & 48 & $2.4 \pm 0.13$ & $1.17 \pm 0.03$ \\
\hline $1,25(\mathrm{OH})_{2} \mathrm{D}_{3}$ & 48 & $4.0 \pm 0.30^{*}$ & $1.15 \pm 0.03$ \\
\hline
\end{tabular}

The ratio of the TRH-induced peak response in $\left[\mathrm{Ca}^{2+}\right]_{\mathrm{i}}$ was calculated relative to the basal $\left[\mathrm{Ca}^{2+}\right]_{i}$ level before TRH addition for each experiment. Values given are mean $\pm \mathrm{SE}$ for seven determinations at $24 \mathrm{~h}$ and 16 determinations at $48 \mathrm{~h}$ obtained from 5 and 12 independent experiments, respectively, in which both treatment groups were represented in the same experiment.

* Significantly different from vehicle control $P<0.05$.

$\mathrm{nM}(n=17)$, respectively $(P>0.05)$. However the $\left[\mathrm{Ca}^{2+}\right]_{\mathrm{i}}$ peak value achieved in response to TRH was significantly $(P<0.05)$ enhanced by pretreatment with $1,25(\mathrm{OH})_{2} \mathrm{D}_{3}$ for either 24 or $48 \mathrm{~h}$ (Fig. 2). The TRH-induced peak to basal ratio of $\left[\mathrm{Ca}^{2+}\right]_{\mathrm{i}}$ was 2.4 and 4.0 in control and $48 \mathrm{~h}$ pretreated cells, respectively (Table I). This enhanced intracellular cytosolic calcium increase was restricted to the peak phase of the TRH response. The sustained plateau phase of the TRH response was not significantly affected $(P>0.05)$ by pretreatment with $1,25(\mathrm{OH})_{2} \mathrm{D}_{3}$ for 24 or $48 \mathrm{~h}$ (Fig. 2). TRH-induced plateau to basal ratios of $\left[\mathrm{Ca}^{2+}\right]_{\mathrm{i}}$ were 1.17 and 1.15 in control and $48 \mathrm{~h}$ pretreated cells, respectively (Table I).

Acute exposure to $1 \mathrm{nM} 1,25(\mathrm{OH})_{2} \mathrm{D}_{3}$ did not affect $\left[\mathrm{Ca}^{2+}\right]_{i}$, nor did it enhance the response to TRH (Fig. 3). Basal $\left[\mathrm{Ca}^{2+}\right]_{\mathrm{i}}$ levels were $174 \mathrm{nM}$ before and $166 \mathrm{nM}$ after $15 \mathrm{~min}$ of incubation with $1 \mathrm{nM} 1,25(\mathrm{OH})_{2} \mathrm{D}_{3}$. Subsequent $\left[\mathrm{Ca}^{2+}\right]_{\mathrm{i}}$ levels achieved in response to TRH were also unaffected by this 15-min pretreatment. The TRH-peak/basal ratio was 2.0 and

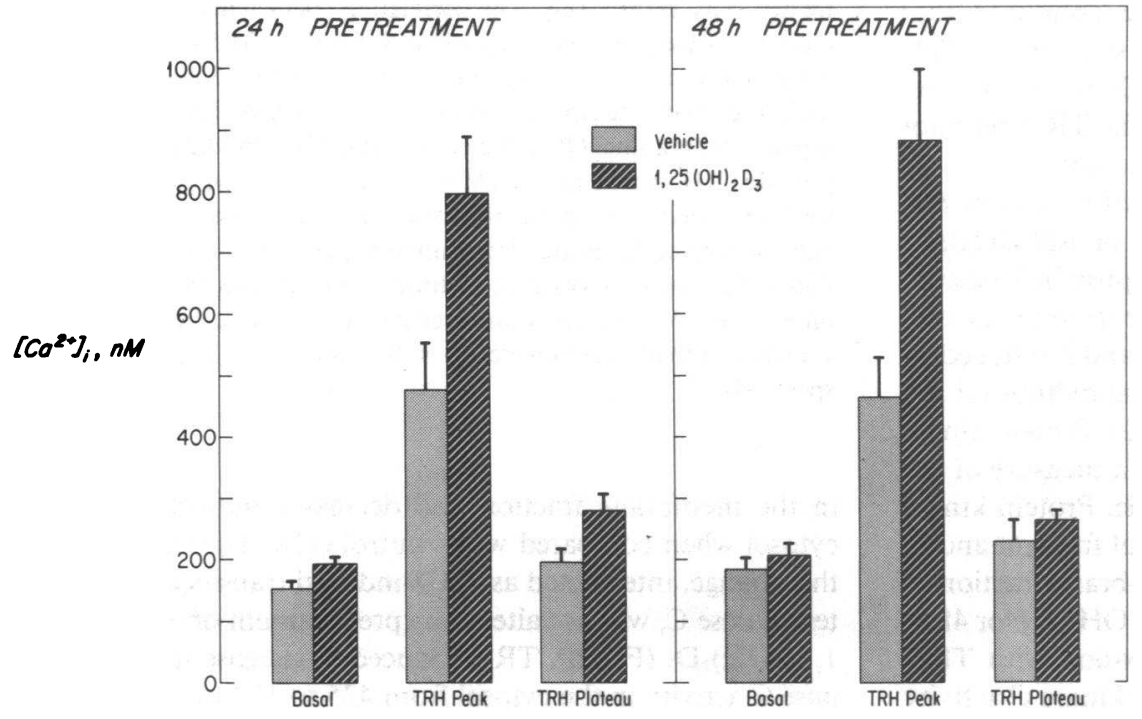

Figure 2. Summary of $\left[\mathrm{Ca}^{2+}\right]_{\mathrm{i}}$ in cells pretreated for 24 or $48 \mathrm{~h}$ without or with $1,25(\mathrm{OH})_{2} \mathrm{D}_{3}(1 \mathrm{nM})$. Data were obtained using quin 2 in experiments similar to those described in Fig. 1. Each bar gives the mean value of five experiments at $24 \mathrm{~h}$ and $16 \mathrm{ex}$ periments at $48 \mathrm{~h}$; the brackets give the SE. TRH responses were measured by addition of $350 \mathrm{nM}$ TRH after initial determination of basal levels of $\left[\mathrm{Ca}^{2+}\right]_{i}$. Enhancement above vehicle-treated control cells of the TRH-induced peak in $\left[\mathrm{Ca}^{2+}\right]_{\mathrm{i}}$ was significant $(P<0.05)$ at both 24 and $48 \mathrm{~h}$ of pretreatment with $1,25(\mathrm{OH})_{2} \mathrm{D}_{3}$. There was no statistically significant difference $(P>0.05)$ in basal $\left[\mathrm{Ca}^{2+}\right]_{\mathrm{i}}$ or in $\mathrm{TRH}_{\text {plat }}$ levels between treated and control cells. 


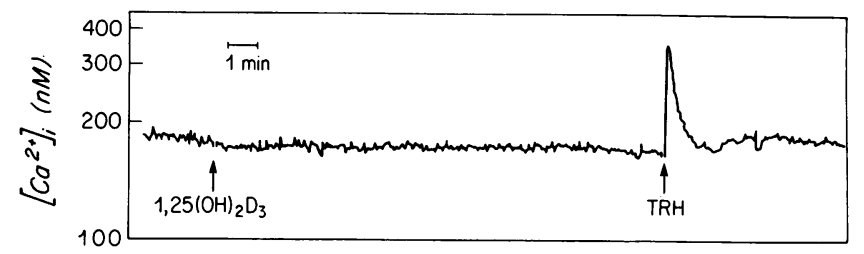

Figure 3. Lack of acute actions of $1,25(\mathrm{OH})_{2} \mathrm{D}_{3}$ on $\left[\mathrm{Ca}^{2+}\right]_{\mathrm{i}}$ in $\mathrm{GH}_{4} \mathrm{C}_{1}$ cells. Monitoring of $\left[\mathrm{Ca}^{2+}\right]_{i}$ was performed as described in Figs. 1 and 2. Cells were grown in serum-free medium for $24 \mathrm{~h}$ before the experiment. $1,25(\mathrm{OH})_{2} \mathrm{D}_{3}(1 \mathrm{nM})$ was added to $7 \times 10^{6}$ quin2-loaded cells at the time indicated. Fluorescence was monitored for $15 \mathrm{~min}$ and then TRH ( $350 \mathrm{nM}$ final concentration) was added. The concentrations of $\left[\mathrm{Ca}^{2+}\right]_{\mathrm{i}}$ in $\mathrm{nM}$ were: basal, 174; $\mathrm{TRH}_{\text {peak }}, 345$; $\mathrm{TRH}_{\text {plateau }}$, 183, ratios were $\mathrm{TRH}_{\text {peak/basal }}, 2.0 ; \mathrm{TRH}_{\text {plateau/basal }}, 1.1$. Cells treated with vehicle alone gave essentially the same response as shown for $1,25(\mathrm{OH})_{2} \mathrm{D}_{3}$-treated cells. This experiment was repeated three times with the same results.

the plateau/basal ratio was 1.1 after this 15 -min pretreatment experiment; these values were not different from those determined for vehicle-treated control cells (Table I).

TRH binding in cells pretreated with $1,25(\mathrm{OH})_{2} \mathrm{D}_{3}$. The vitamin D-induced modulation of the TRH response could be mediated either by a change in the TRH-receptor interaction or a change in intracellular signal transduction. The first possibility was examined by measuring directly the binding of TRH. As indicated by the data shown in Fig. 4, treatment with $1,25(\mathrm{OH})_{2} \mathrm{D}_{3}$ for $48 \mathrm{~h}$ produced no change in the kinetics of binding of $\left[{ }^{3} \mathrm{H}\right] \mathrm{MeTRH}$ to $\mathrm{GH}_{4} \mathrm{C}_{1}$ cells. The $K_{\mathrm{d}}$ 's measured in this experiment were 2.4 and $2.8 \mathrm{~nm}$ for control and treated cells, respectively. The difference between the mean values for control and $1,25(\mathrm{OH})_{2} \mathrm{D}_{3}$-treated cells provided by six independent experiments was $<0.5 \mathrm{nM}$. There was no consistent change in maximal $\left[{ }^{3} \mathrm{H}\right] \mathrm{MeTRH}$ binding in five paired determinations. The mean difference between control and treated groups was $2 \%$. Treatment with $1,25(\mathrm{OH})_{2} \mathrm{D}_{3}$ produced no change in cell number or total cell protein per well, with a mean difference between the treatment groups of $<4 \%$ in six separate experiments. Finally, the time course of binding at early time points was unaffected by $1,25(\mathrm{OH})_{2} \mathrm{D}_{3}$ pretreatment (Fig. $4 B$ ). The mean difference was $<5 \%$ across all 18 paired time points in four separate experiments and showed no trend with respect to time of incubation. We conclude that $1,25(\mathrm{OH})_{2} \mathrm{D}_{3}$ pretreatment does not enhance steady state TRH binding, a finding that suggests that vitamin $\mathrm{D}$ acts by a postreceptor mechanism. Signal transduction via the TRH receptor was then examined at four possible sites of action.

$T R H$-induced protein kinase $C$ translocation in cells pretreated with $1,25(\mathrm{OH})_{2} D_{3}$. Activation of the phosphatidylserine- and calcium-dependent protein kinase (protein kinase C) is correlated with translocation of the enzyme from the cytosol to the membrane fraction of the cell $(22,25)$ and is induced by DAG, one of the active products of phosphatidylinositol hydrolysis following TRH receptor occupancy (2). Protein kinase $\mathrm{C}$ translocation was, therefore, examined as a measure of the DAG branch of the phosphoinositide cascade. Protein kinase $\mathrm{C}$ activity was measured in the soluble cytosol fraction and in the Triton X-100-extracted particulate membrane fraction of control cells and cells treated with $1 \mathrm{nM} 1,25(\mathrm{OH})_{2} \mathrm{D}_{3}$ for $48 \mathrm{~h}$. As described previously (22), $15 \mathrm{~s}$ of incubation with TRH increases dramatically the amount of protein kinase $\mathrm{C}$ activity
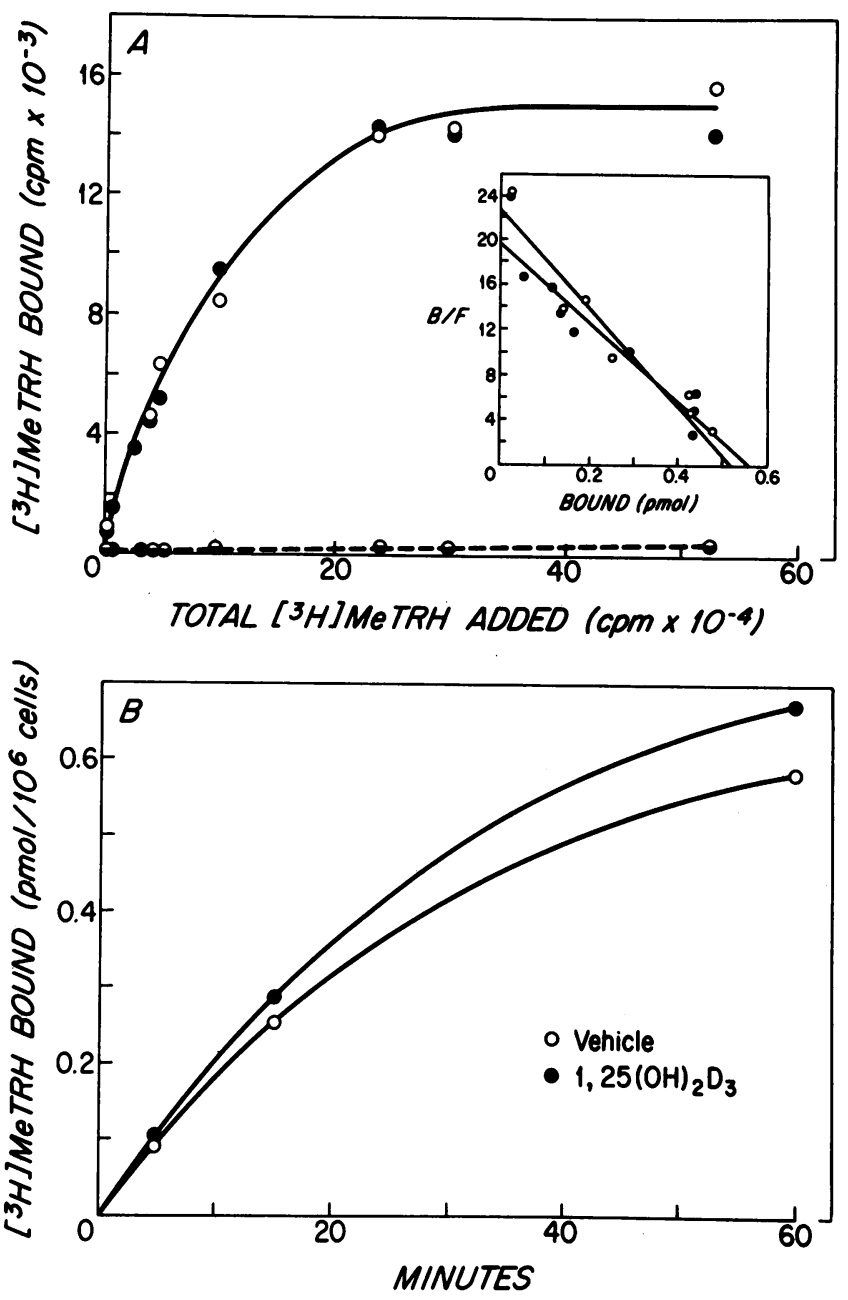

Figure 4. Binding of $\left[{ }^{3} \mathrm{H}\right] \mathrm{MeTRH}$ to cells treated without and with 1 $\mathrm{nM} 1,25(\mathrm{OH})_{2} \mathrm{D}_{3}$ for $48 \mathrm{~h}$. Cells were incubated with ligand at $37^{\circ} \mathrm{C}$ in $5 \% \mathrm{CO}_{2}$. Specific binding (on ordinates) was calculated as total binding minus the amount of $\left[{ }^{3} \mathrm{H}\right] \mathrm{MeTRH}$ bound in the presence of $(1.5 \mu \mathrm{M})$ unlabeled MeTRH as described in Methods. (A) Adsorption isotherms for equilibrium binding after $60 \mathrm{~min}$ at concentrations of $\left[{ }^{3} \mathrm{H}\right] \mathrm{MeTRH}$ ranging from 0.1 to $16.0 \mathrm{nM}$. Values derived from Scatchard transformations of these data (inset) indicate equilibrium dissociation constants $\left(K_{\mathrm{d}}\right)$ of 2.2 and $2.8 \mathrm{nM}$ and maximal binding $\left(B_{\max }\right)$ of 1.2 and $1.3 \mathrm{pmol} / \mathrm{mg}$ protein for vehicle and treated cells, respectively. The correlation coefficients of the linear regressions used in these determinations were $>0.95$ in both groups. Total cell protein concentrations were 0.43 and $0.46 \mathrm{mg} /$ well for vehicle and treated samples, respectively. The dashed line indicates nonspecific binding. $(B)$ Time course of specific binding of $1.5 \mathrm{nM}$ $\left[{ }^{3} \mathrm{H}\right] \mathrm{MeTRH}$ to cells pretreated with vehicle or $1 \mathrm{nM} 1,25(\mathrm{OH})_{2} \mathrm{D}_{3}$ for $48 \mathrm{~h}$. Total binding was the mean of quadruplicate, and nonspecific binding of duplicate, determinations at 5 and $15 \mathrm{~min}$, the $\mathrm{SE}$ falls within the symbols at these time points. Binding was measured on cells in $1.5 \mathrm{ml}$ of the serum-free growth medium. Cell counts for vehicle and treated cells were $3.0 \times 10^{5}$ and $2.8 \times 10^{5}$ per well, respectively.

in the membrane fraction and decreases the activity in the cytosol when compared with control cells. The magnitude of this change, interpreted as TRH-induced translocation of protein kinase $C$, was not altered by pretreatment of the cells with $1,25(\mathrm{OH})_{2} \mathrm{D}_{3}$ (Fig. 5). TRH induced a decrease in protein kinase $\mathrm{C}$ activity in the cytosol from 425 to $193 \mathrm{nmol} \mathrm{min}^{-1} \mathrm{mg}$ 


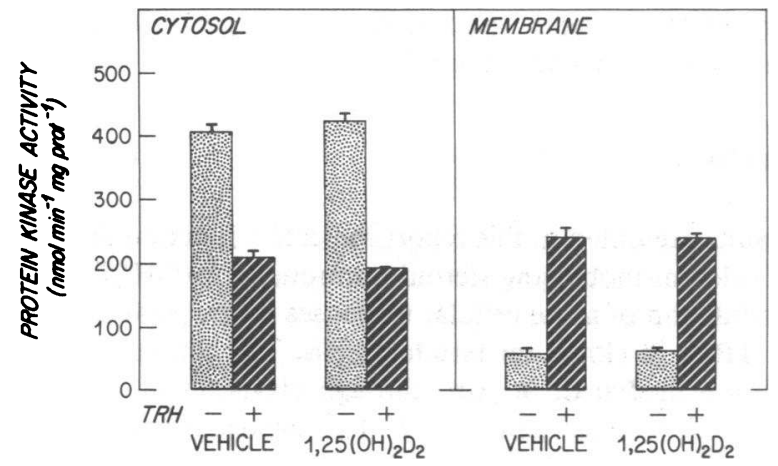

Figure 5. TRH-induced protein kinase $\mathrm{C}$ translocation in control cells and cells pretreated with $1,25(\mathrm{OH})_{2} \mathrm{D}_{3}$. Cells were grown in chemically defined medium and treated without or with $1 \mathrm{nM}$ $1,25(\mathrm{OH})_{2} \mathrm{D}_{3}$ for $48 \mathrm{~h}$. After $15 \mathrm{~s}$ of incubation without or with TRH $(1 \mu \mathrm{M})$, cells were ruptured and membranes rapidly separated from cytosol. Fractions were obtained from DEAE chromatography of both the cytosol and the Triton-solubilized membranes. Phosphatidylserine and $\mathrm{Ca}^{2+}$-dependent protein kinase $\mathrm{C}$ activity was measured in these fractions as the amount of ${ }^{32} \mathrm{P}$ transferred from ATP to a histone acceptor. Each bar gives the mean of duplicate samples and the brackets give the ranges. The experiment was repeated once with similar results.

protein $^{-1}$ in $1,25(\mathrm{OH})_{2}$-treated cells and from 410 to $209 \mathrm{nmol}$ $\mathrm{min}^{-1} \mathrm{mg}$ protein ${ }^{-1}$ in control cytosol fractions. Conversely, protein kinase $\mathrm{C}$ activity increased in the membrane fraction from 57 to 238 and 58 to $240 \mathrm{nmol} \mathrm{m^{-1 } \mathrm { mg } \text { protein }}{ }^{-1}$ in $1,25(\mathrm{OH})_{2} \mathrm{D}_{3}$-pretreated and control membrane fractions, respectively. We conclude that this DAG-mediated function of TRH is not enhanced by $1,25(\mathrm{OH})_{2} \mathrm{D}_{3}$.

TRH-induced formation of inositol phosphates in cells pretreated with $1,25(\mathrm{OH})_{2} D_{3}$. Inositol phosphates are representative of the second branch of the phosphatidylinositol hydrolysis cascade (16). $\mathrm{IP}_{3}$ is currently believed to cause the release of intracellular calcium stores and the majority of the peak phase of the TRH response in GH cells. TRH-induced phosphatidylinositol 4,5-bisphosphate hydrolysis was examined by measuring the production of $\mathrm{IP}_{3}$ as well as its subsequent metabolites, inositol bisphosphate and inositol phosphate. Data from several such experiments are summarized in Fig. 6 . The ordinate gives the ratio of metabolite accumulation in TRH-treated cells to unstimulated control cells. Pretreatment with $1,25(\mathrm{OH})_{2} \mathrm{D}_{3}$ for 12,24 , or $48 \mathrm{~h}$ did not affect $\mathrm{IP}_{3}$ production in response to TRH. We conclude that the hydrolysis of polyphosphatidylinositol induced by TRH is not enhanced by pretreatment with $1,25(\mathrm{OH})_{2} \mathrm{D}_{3}$.

Ionomycin-induced response in $\left[\mathrm{Ca}^{2+}\right]_{i}$ in cells pretreated with $1,25(\mathrm{OH})_{2} D_{3}$. Because phosphatidylinositol metabolism induced by TRH was unaffected by $1,25(\mathrm{OH})_{2} \mathrm{D}_{3}$ pretreatment, we examined whether pretreatment with vitamin $D$ altered the size of the TRH-releasable intracellular calcium pool. The magnitude of this pool of calcium was estimated by releasing it with the ionophore ionomycin. The peak levels of $\left[\mathrm{Ca}^{2+}\right]_{\mathrm{i}}$ achieved by $100 \mathrm{nM}$ ionomycin treatment were not enhanced by $48 \mathrm{~h}$ pretreatment with $1 \mathrm{nM} 1,25(\mathrm{OH})_{2} \mathrm{D}_{3}$ (Table II). Mean peak to basal ratios were $\cdot 3.4 \pm 0.56$ and $3.8 \pm 0.98$ in $1,25(\mathrm{OH})_{2} \mathrm{D}_{3}$-pretreated and control cells, respectively. In these experiments basal levels of $\left[\mathrm{Ca}^{2+}\right]_{i}$ were again not significantly different in pretreated and control cells (210 and $197 \mathrm{nM}$, respectively). Experiments using a second addi-

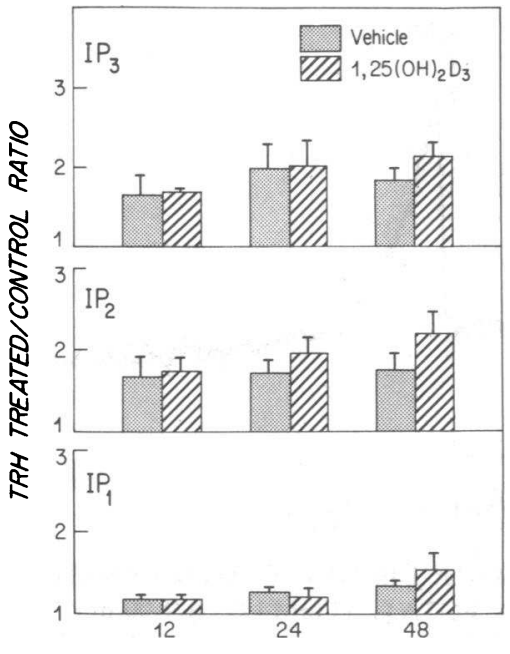

Figure 6. TRH-induced formation of inositol phosphates in cells pretreated with

$1,25(\mathrm{OH})_{2} \mathrm{D}_{3}$. Cells were grown in chemically defined medium with $m y o\left[2-{ }^{3} \mathrm{H}(N)\right]-$ inositol $(8 \mu \mathrm{Ci} / 10 \mathrm{ml})$ for a total of $72 \mathrm{~h}$ and treated without or with $1 \mathrm{nM} 1,25(\mathrm{OH})_{2} \mathrm{D}_{3}$ for the final 12,24 , or $48 \mathrm{~h}$ before testing. Harvested cells were then suspended in HBSS II and incubated with TRH $(1.5 \mu \mathrm{M}, 5$ or 10 s) at $37^{\circ} \mathrm{C}$. The reaction was stopped by cold TCA addition, the su-

pernatant fractions were ether extracted, and inositol phosphates separated by ion exchange chromatography. Quantities given are the ratios of counts per minute per milligram protein obtained from TRH-treated cells vs. counts per minute per milligram protein from unstimulated control cells and represent the mean \pm SE of 3 experiments at $12 \mathrm{~h} ; 4$ experiments at $24 \mathrm{~h}$; and 11 experiments at $48 \mathrm{~h}$. Absolute counts per minute measured in the $\mathrm{IP}_{3}$ fraction of TRHstimulated cells pretreated with $1,25(\mathrm{OH})_{2} \mathrm{D}_{3}$ for $48 \mathrm{~h}$ was 2311 (mean of triplicate determination from a single experiment), for example. There was no significant difference between treated and control cells for any measure $(P>0.05$, Student's $t$ test).

tion of ionomycin (total final concentration $200 \mathrm{nM}$ ) did not stimulate a second $\left[\mathrm{Ca}^{2+}\right]_{\mathrm{i}}$ response, indicating that the quantity of ionomycin used was a maximally effective dose for inducing a peak in $\left[\mathrm{Ca}^{2+}\right]_{\mathrm{i}}$ (data not shown). We conclude that the size of the intracellular calcium pool released by ionomycin, and thus that also releasable by TRH, was not enhanced by pretreatment with $1,25(\mathrm{OH})_{2} \mathrm{D}_{3}$.

$T R H$-induced increase in $\left[\mathrm{Ca}^{2+}\right]_{i}$ during chelation of extracellular calcium in cells pretreated with $1,25(\mathrm{OH})_{2} \mathrm{D}_{3}$. The contribution that influx of extracellular calcium provides to the TRH response was examined to determine if $1,25(\mathrm{OH})_{2} \mathrm{D}_{3}$

Table II. Ionomycin-induced Change in $\left[\mathrm{Ca}^{2+}\right]_{i}$ in Cells Pretreated with $1,25(\mathrm{OH})_{2} \mathrm{D}_{3}$

\begin{tabular}{lcc}
\hline \multicolumn{1}{c}{ Treatment } & Basal $\left[\mathrm{Ca}^{2+}\right]_{\mathrm{i}}$ & $\frac{\left[\mathrm{Ca}^{2+}\right]_{\mathrm{i}} \text { Ratio }}{\text { Ionopraak/nama }}$ \\
\hline$n M$ & \\
Vehicle & $197 \pm 33$ & $3.8 \pm 0.98$ \\
$1,25(\mathrm{OH})_{2} \mathrm{D}_{3}$ & $210 \pm 31$ & $3.4 \pm 0.56$ \\
\hline
\end{tabular}

Cells were grown in chemically defined medium and pretreated without or with $1 \mathrm{nM} 1,25(\mathrm{OH})_{2} \mathrm{D}_{3}$ for $48 \mathrm{~h}$. $\left[\mathrm{Ca}^{2+}\right]_{\mathrm{i}}$ was monitored in experiments similar to those presented in Fig. 1. Ionomycin (100 $\mathrm{nM}$ ) was added after baseline measurements were obtained. Basal levels are measured values for $\left[\mathrm{Ca}^{2+}\right]_{\mathrm{i}}($ mean $\pm \mathrm{SE})$; ratios presented are peak values relative to basal levels, determined by calibration in each experiment. Values given are mean $\pm S E$ for five separate determinations. 


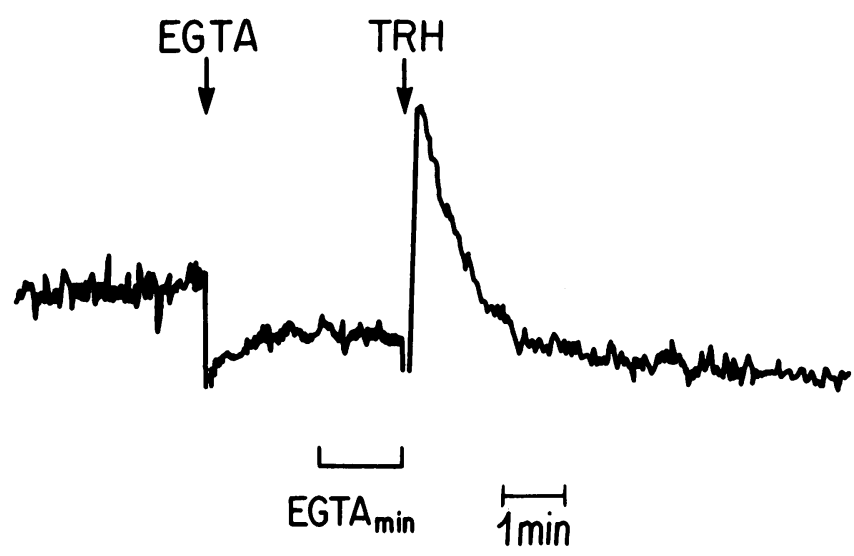

Figure 7. Typical response of $\left[\mathrm{Ca}^{2+}\right]_{i}$ to TRH during chelation of extracellular calcium by EGTA. EGTA (1.33 mM EGTA/1.00 mM $\mathrm{Ca}^{2+}$ ) was added at the time indicated and a new baseline allowed to stabilize for $3 \mathrm{~min}$. TRH was then added at the time indicated. Basal $\left[\mathrm{Ca}^{2+}\right]_{i}$, EGTA $A_{\min }$, and TRH peak levels were 260,230 , and $465 \mathrm{nM}$, respectively. The plateau phase of the TRH response (see Fig. 1) was eliminated by addition of EGTA.

modulates plasma membrane calcium conductance. The size of the extracellular calcium contribution to the response was examined by measuring the TRH-induced peak in the absence of extracellular calcium. During conditions of acute chelation of extracellular calcium by EGTA, $\left[\mathrm{Ca}^{2+}\right]_{i}$ decreased from basal control levels and stabilized quickly $(<3 \mathrm{~min})$ at a new lower value $\left(\right.$ EGTA $_{\min }$ ) (see Fig. 7). Subsequently, TRH produced a spike in $\left[\mathrm{Ca}^{2+}\right]_{i}$ that was only slightly attenuated in comparison with cells not treated with EGTA; on the other hand, the plateau phase of the TRH response in $\left[\mathrm{Ca}^{2+}\right]_{i}$ was completely abolished by EGTA $(4,5)$. The size of the peak response to TRH was determined for cells pretreated for $48 \mathrm{~h}$ without or with $1,25(\mathrm{OH})_{2} \mathrm{D}_{3}$. As summarized in Table III, addition of EGTA lowered basal $\left[\mathrm{Ca}^{2+}\right]_{\mathrm{i}}$ to the same extent in $1,25(\mathrm{OH})_{2} \mathrm{D}_{3}$-treated and control cells $\left(\mathrm{EGTA}_{\min } /\right.$ basal ratio of 0.86 and 0.77 , respectively). Notably however, chelation of extracellular calcium reduced or eliminated the enhancement by $1,25(\mathrm{OH})_{2} \mathrm{D}_{3}$ of the TRH-induced peak in $\left[\mathrm{Ca}^{2+}\right]_{i}$. The TRH peak/EGTA $A_{\min }$ ratios were 3.1 and 2.6 in pretreated and control cells, respectively. This difference was not statistically significant. Thus, during conditions of extracellular calcium chelation, the acute TRH-induced increase in $\left[\mathrm{Ca}^{2+}\right]_{i}$ was no longer greater in cells pretreated with $1,25(\mathrm{OH})_{2} \mathrm{D}_{3}$ than it was in control cells. We conclude that $1,25(\mathrm{OH})_{2} \mathrm{D}_{3}$-induced en- hancement of the acute response to TRH depends upon the presence of extracellular calcium.

\section{Discussion}

The results presented in this report indicate a function for the classic calcium-mobilizing steroid hormone, $1,25(\mathrm{OH})_{2} \mathrm{D}_{3}$, in the modulation of acute cellular responses to the peptide hormone, TRH, in clonal rat pituitary cells. The actions of this peptide are mediated, in part, through elevation of $\left[\mathrm{Ca}^{2+}\right]_{i}$. Basal $\left[\mathrm{Ca}^{2+}\right]_{\mathrm{i}}$ was unaffected by pretreatment with $1,25(\mathrm{OH})_{2} \mathrm{D}_{3}$, either acutely $(15 \mathrm{~min})$ or for periods of up to 48 h. Moreover, the biphasic pattern of TRH-mediated changes in $\left[\mathrm{Ca}^{2+}\right]_{\mathrm{i}}$ remained qualitatively the same, with an initial peak achieved within seconds, followed, after its nadir, by a prolonged plateau elevation. However, pretreatment of the cells with $1,25(\mathrm{OH})_{2} \mathrm{D}_{3}$ for 24 or $48 \mathrm{~h}$ caused a substantial increase in the size of the initial $\left[\mathrm{Ca}^{2+}\right]_{i}$ peak response to TRH. Because intracellular calcium levels have been shown to be an important component of signal transduction for this secretagogue, we were particularly interested in determining the mechanism of action of $1,25(\mathrm{OH})_{2} \mathrm{D}_{3}$ on this TRH-induced calcium response. Furthermore, the mechanism underlying 1,25$(\mathrm{OH})_{2} \mathrm{D}_{3}$-induced calcium uptake in more classical target tissues has remained elusive. Thus, investigations in $\mathrm{GH}_{4} \mathrm{C}_{1}$ cells may provide insights valuable to the more intractable in vivo situation.

Actions of $1,25(\mathrm{OH})_{2} \mathrm{D}_{3}$ on increasing extracellular calcium uptake have been described in vivo (as early as $14 \mathrm{~min}$ after exposure in vitamin D-depleted chick intestine [26]), for example. Much of the accumulated data indicate that the hormone acts via a classical steroid receptor mechanism $(11,12)$. Labeled $1,25(\mathrm{OH})_{2} \mathrm{D}_{3}$ has been localized in cell nuclei in such classical target tissues as epithelial cells of the intestine and distal convoluted tubule of the kidney, where its actions are known to be involved in the maintenance of plasma calcium and inorganic phosphorus homeostasis. Several nonclassical target sites, including anterior pituitary tissue in the rat, also demonstrate nuclear uptake of the hormone, and subsequent analysis confirmed the presence of specific receptors for $1,25(\mathrm{OH})_{2} \mathrm{D}_{3}$ in these nonclassical tissues (27).

The mechanism or mechanisms underlying the transduction of vitamin D receptor activation to calcium uptake has been the subject of intensive investigation. Although several proteins have been shown to be induced by this hormone, including at least four different (based on molecular weight

Table III. TRH-induced Elevation of $\left[\mathrm{Ca}^{2+}\right]_{i}$ in Cells Pretreated with $1,25(\mathrm{OH})_{2} \mathrm{D}_{3}$ during Chelation of Extracellular Ca ${ }^{2+}$

\begin{tabular}{|c|c|c|c|c|c|c|}
\hline \multirow[b]{3}{*}{ Treatment } & \multirow{2}{*}{\multicolumn{3}{|c|}{$\left[\mathrm{Ca}^{2+}\right]_{\mathrm{i}}(n M)$}} & \multicolumn{3}{|c|}{ Ratios } \\
\hline & & & & \multirow{2}{*}{$\frac{\text { EGTA }_{\min }}{\text { Basal }}$} & \multirow{2}{*}{$\frac{\text { TRH peak }}{\text { EGTA }_{\min }}$} & \multirow{2}{*}{$\frac{\text { TRH peak }}{\text { Basal }}$} \\
\hline & Basal & EGTA $_{\min }$ & TRH peak & & & \\
\hline Vehicle & $279 \pm 34$ & $207 \pm 31$ & $501 \pm 52$ & $0.77 \pm 0.09$ & $2.6 \pm 0.36$ & $1.9 \pm 0.24$ \\
\hline $1,25(\mathrm{OH})_{2} \mathrm{D}_{3}$ & $257 \pm 27$ & $220 \pm 30$ & $628 \pm 81$ & $0.86 \pm 0.04$ & $3.1 \pm 0.47$ & $2.6 \pm 0.43$ \\
\hline
\end{tabular}

Quantities presented are absolute values of $\left[\mathrm{Ca}^{2+}\right]_{i}$, and ratios of absolute $\left[\mathrm{Ca}^{2+}\right]_{i}$ after EGTA and TRH addition, relative to prechelation basal $\left[\mathrm{Ca}^{2+}\right]_{\mathrm{i}}$ levels and EGTA ${ }_{\min }$, respectively. Values given are means $\pm \mathrm{SE}$ of five or more determinations from three independent experiments. There was no statistically significant difference between $1,25(\mathrm{OH})_{2} \mathrm{D}_{3}$-pretreated and control cells in any measurements. 
analyses) $1,25(\mathrm{OH})_{2} \mathrm{D}_{3}$-dependent calcium binding proteins, these proteins make their appearance well after the initiation of calcium uptake, and none has remained a candidate for mediator of this effect (28). Alternatively, Matsumoto et al. (29) have presented evidence for a direct effect of the steroid hormone on plasma membrane fluidity via an increase in the phosphatidylcholine/phosphatidylethanolamine ratio using membranes derived from chick intestine. On the other hand, our data demonstrate an action in $\mathrm{GH}_{4} \mathrm{C}_{1}$ cells on membrane calcium conductance. We have demonstrated that neither basal $\left[\mathrm{Ca}^{2+}\right]_{i}$ nor the sustained elevation of $\left[\mathrm{Ca}^{2+}\right]_{i}$ in response to TRH are measurably affected by pretreatment with the steroid in this pituitary cell strain. Furthermore, the $1,25(\mathrm{OH})_{2} \mathrm{D}_{3}$-induced enhancement of the peak $\left[\mathrm{Ca}^{2+}\right]_{i}$ response required pretreatment times $>15 \mathrm{~min}$, precluding direct effects of the steroid on the plasma membrane. Because the binding of $\left[{ }^{3} \mathrm{H}\right] \mathrm{MeTRH}$ was unchanged by $1,25(\mathrm{OH})_{2} \mathrm{D}_{3}$ pretreatment, we examined the intracellular events responsible for mobilizing the TRH-induced calcium peak to determine where the steroid hormone was exerting its action. We found no change in the dynamics of phosphatidylinositol hydrolysis, as determined by measuring either the activation of protein kinase $\mathrm{C}$ or the accumulation of inositol phosphates subsequent to TRH stimulation. The intracellular calcium pool was not enhanced by $1,25(\mathrm{OH})_{2} \mathrm{D}_{3}$ pretreatment, as measured by mobilization with a low concentration of ionomycin. Under conditions of acute chelation of extracellular calcium, however, we found that the TRH-induced spike in $\left[\mathrm{Ca}^{2+}\right]_{i}$ was no longer enhanced in $1,25(\mathrm{OH})_{2} \mathrm{D}_{3}$ pretreated cells. Thus, the vitamin D-enhanced calcium peak appears to depend on extracellular calcium. This suggests an enhancement of calcium conductance at the level of the plasma membrane. This might result from a greater number of TRH-operated calcium channels, a larger conductance of existing channels, decreased calcium efflux or redistribution within the cell, or some combination of these actions. Alternatively, enhanced loading of an intracellular calcium pool that is ionomycin-resistant, EGTAsensitive, and TRH-mobilizable is also possible.

Intracellular $\left[\mathrm{Ca}^{2+}\right]$ transients have been related functionally to the TRH-induced biphasic secretion pattern from $\mathrm{GH}_{4} \mathrm{C}_{1}$ cells (5). Both the $\left[\mathrm{Ca}^{2+}\right]_{i}$ rise and hormone secretion, for example, can be blocked in parallel by agents that block either the initial or the sustained stages of the biphasic response. Thus, the physiological relevance of the enhanced calcium response in $1,25(\mathrm{OH})_{2} \mathrm{D}_{3}$-pretreated cells might be expected to include an enhanced initial release of PRL in response to TRH. Preliminary experiments to measure TRH-stimulated PRL release from $1,25(\mathrm{OH})_{2} \mathrm{D}_{3}$ pretreated cells have, thus far, given inconsistent results. In six of seven experiments, the amount (nanograms per milligram cell protein) of PRL released from $1,25(\mathrm{OH})_{2} \mathrm{D}_{3}$ pretreated cells was greater than the amount released from control cells by $82 \pm 37 \%$ (mean $\pm \mathrm{SE}, n=6$ ), at the earliest timepoints ( 0.5 to $2.5 \mathrm{~min}$ ) of measured stimulation of PRL release. However, the time at which the enhanced secretory response was observed has not been the same across all experiments; we have, as yet, no explanation for the variability in these results. Two recent reports $(31,32)$ have indicated that $1,25(\mathrm{OH})_{2} \mathrm{D}_{3}$ produces enhancement of TRH-induced secretion from rat pituitary cells maintained in primary culture. Such results support the hypothesis of a function for vitamin D in the secretory actions of TRH.

\section{Acknowledgments}

We thank Dr. Clare Fearon for assistance with protein kinase $C$ assays; Dr. John Ramsdell and Nancy Sullivan for assistance with the assay for inositol polyphosphates; and Jean Foley for assistance in preparation of the manuscript.

This research was supported in part by research grants from the National Institutes of Health (DK-11011 and DK-10206).

\section{References}

1. Berridge, M. J., and R. F. Irvine. 1984. Inositol trisphosphate, a novel second messenger in cellular signal transduction. Nature (Lond.). 312:315-321.

2. Hirasawa, K., and Y. Nishizuka. 1985. Phosphatidylinositol turnover in receptor mechanism and signal transduction. Annu. Rev. Pharmacol. Toxicol. 25:147-170.

3. Rasmussen, H., and P. Q. Barrett. 1984. Calcium messenger system. An integrated view. Physiol. Rev. 64:938-984.

4. Albert, P. R., and A. H. Tashjian, Jr. 1984. Thyrotropin-releasing hormone-induced spike and plateau in cytosolic free $\mathrm{Ca}^{2+}$ concentrations in pituitary cells. Relation to prolactin release. J. Biol. Chem. 259:5827-5832.

5. Albert, P. R., and A. H. Tashjian, Jr. 1984. Relationship of thyrotropin-releasing hormone-induced spike and plateau phases in cytosolic free $\mathrm{Ca}^{2+}$ concentrations to hormone secretion. Selective blockade using ionomycin and nifedipine. J. Biol. Chem. 259:1535015363.

6. Martin, T. F. J., and J. A. Kowalchyk. 1984. Evidence for the role of calcium and diacylglycerol as dual second messengers in thyrotropin-releasing hormone action. Involvement of $\mathrm{Ca}^{2+}$. Endocrinology. 115:1527-1536.

7. Aizawa, T., and P. M. Hinkle. 1985. Thyrotropin-releasing hormone rapidly stimulates a biphasic secretion of prolactin and growth hormone in $\mathrm{GH}_{4} \mathrm{C}_{1}$ rat pituitary tumor cells. Endocrinology. 116:7382.

8. Gershengorn, M. C., and C. Thaw. 1985. Thyrotropin-releasing hormone (TRH) stimulates biphasic elevation of cytoplasmic free calcium in $\mathrm{GH}_{3}$ cells. Further evidence that TRH mobilizes cellular and extracellular $\mathrm{Ca}^{2+}$. Endocrinology. 116:591-596.

9. Wark, J. D., and A. H. Tashjian, Jr. 1982. Vitamin D stimulates prolactin synthesis by $\mathrm{GH}_{4} \mathrm{C}_{1}$ cells incubated in chemically defined medium. Endocrinology. 111:1755-1757.

10. Wark, J. D., and A. H. Tashjian, Jr. 1983. Regulation of prolactin mRNA by 1,25 -dihydroxyvitamin $\mathrm{D}_{3}$ in $\mathrm{GH}_{4} \mathrm{C}_{1}$ cells. J. Biol. Chem. 258:12118-12121.

11. Deluca, H. F., and H. K. Schnoes. 1983. Vitamin D: Recent advances. Annu. Rev. Biochem. 52:411-439.

12. Bell, N. H. 1985. Vitamin D-endocrine system. J. Clin. Invest. 76:1-6.

13. Rebecchi, M. J., and M. C. Gershengorn. 1983. Thyroliberin stimulates rapid hydrolysis of phosphatidylinositol 4,5-bisphosphate by a phosphodiesterase in rat mammotropic pituitary cells. Biochem. J. 216:287-294.

14. Drummond, A. H., R. J. Knox, and C. H. Macphee. 1985. The role of inositol lipids in hormonal mobilization of cell-associated $\mathrm{Ca}^{2+}$. Biochem. Soc. Trans. 13:58-60.

15. Martin, T. F. J. 1983. Thyrotropin-releasing hormone rapidly activates the phosphodiester hydrolysis of polyphosphoinositides in $\mathrm{GH}_{3}$ pituitary cells. Evidence for the role of a polyphosphoinositidespecific phospholipase $\mathrm{C}$ in hormone action. J. Biol. Chem. 258:14816-14822.

16. Berridge, M. J. 1986. Regulation of ion channels by inositol trisphosphate and diacylglycerol. J. Exp. Biol. 124:323-335.

17. Tashjian, A. H., Jr., Y. Yasumura, L. Levine, G. H. Sato, and M. L. Parker. 1968. Establishment of clonal strains of rat pituitary tumor cells that secrete growth hormone. Endocrinology. 82:342-352. 
18. Tashjian, A. H., Jr. 1979. Clonal strains of hormone-producing pituitary cells. Methods Enzymol. 58:527-535.

19. Tsien, R. Y. 1980. New calcium indicators and buffers with high selectivity against magnesium and protons. Design, synthesis, and properties of prototype structures. Biochemistry. 19:2396-2404.

20. Tsien, R. Y. 1981. A non-disruptive technique for loading calcium buffers and indicators into cells. Nature (Lond.). 290:527-528.

21. Leach, K. L., M. L. James, and P. M. Blumberg. 1983. Characterization of a specific phorbol ester aporeceptor in mouse brain cytosol. Proc. Natl. Acad. Sci. USA. 80:4208-4212.

22. Fearon, C. W., and A. H. Tashjian, Jr. 1985. Thyrotropin-releasing hormone induces redistribution of protein kinase $\mathrm{C}$ in $\mathrm{GH}_{4} \mathrm{C}_{1}$ rat pituitary cells. J. Biol. Chem. 260:8366-8371.

23. Ramsdell, J. S., and A. H. Tashjian, Jr. 1986. Thyrotropin-releasing hormone (TRH) elevation of inositol trisphosphate and cytosolic free calcium is dependent on receptor number. Evidence for multiple rapid interactions between TRH and its receptor. J. Biol. Chem. 261:5301-5306.

24. Griffin, H. D., and J. N. Hawthorne. 1978. Calcium-activated hydrolysis of phosphatidyl-myo-inositol 4-phosphate and phosphatidyl-myo-inositol 4,5-bisphosphate in guinea pig synaptosomes. Biochem. J. 176:541-552.

25. Kraft, A. S., and W. B. Anderson. 1983. Phorbol esters increase the amount of $\mathrm{Ca}^{2+}$, phospholipid-dependent protein kinase associated with plasma membrane. Nature (Lond.). 301:621-623.

26. Nemere, I., Y. Yoshimoto, and A. W. Norman. 1984. Calcium transport in perfused duodena from normal chicks. Enhancement within fourteen minutes of exposure to 1,25-dihydroxyvitamin $D_{3}$. Endocrinology. 115:1476-1483.

27. Haussler, M. R., S. C. Manolagas, and L. J. Deftos. 1980. Evidence for a 1,25-dihydroxyvitamin $\mathrm{D}_{3}$ receptor-like macromolecule in rat pituitary. J. Biol. Chem. 255:5007-5010.

28. Norman, A. W., J. Roth, and L. Orci. 1982. The vitamin D endocrine system: steroid metabolism, hormone receptors, and biological response (calcium binding proteins). Endocrinol. Rev. 3:331-366.

29. Matsumoto, T., O. Fontaine, and H. Rasmussen. 1981. Effect of 1,25-dihydroxyvitamin $\mathrm{D}_{3}$ on phospholipid metabolism in chick duodenal mucosal cell. Relationship to its mechanism of action. $J$. Biol. Chem. 256:3354-3360.

30. Drummond, A. H. 1986. Inositol lipid metabolism and signal transduction in clonal pituitary cells. J. Exp. Biol. 124:337-358.

31. Törnquist, K., and C. Lamberg-Allardt. 1987. Effect of 1,25-dihydroxyvitamin $D_{3}$ on TSH secretion from rat pituitary cells in culture. Acta Endocrinol. (Copenh.) 114:357-361.

32. D'emden, M., and J. D. Wark. 1987. 1,25-dihydroxyvitamin $D_{3}$ enhances thyrotropin releasing hormone induced thyrotropin secretion in normal pituitary cells. Endocrinology. 121:1192-1194. 